\title{
Life on the edge: do biomechanical and behavioral adaptations to wave-exposure correlate with habitat partitioning in predatory whelks?
}

\author{
Gil Rilov ${ }^{1,3, *}$, Yehuda Benayahu ${ }^{2}$, Avital Gasith ${ }^{1}$ \\ ${ }^{1}$ Institute for Nature Conservation Research, ${ }^{2}$ Department of Zoology, George S. Wise Faculty of Life Sciences, \\ Tel-Aviv University, Ramat-Aviv, Tel-Aviv 69978, Israel \\ ${ }^{3}$ Present address: Marine Ecology Research Group, School of Biological Sciences, University of Canterbury,
} Private Bag 4800, Christchurch, New Zealand

\begin{abstract}
The rocky littoral is a highly stressed but species rich environment in which adaptive trade-offs underlie the specialization that permits habitat partitioning by closely-related species. Habitat partitioning by prey species is generally attributed to differential tolerances to physiological stresses and competition for resources. Partitioning by predators is, however, less understood and also mainly related to thermal tolerance. We test the hypothesis that differential biomechanical and behavioral adaptations to wave action can result in habitat partitioning of mobile predators using 2 Mediterranean whelks. Stramonita haemastoma is found mainly at wave-exposed habitats on lower midlittoral or shallow (1 to $3 \mathrm{~m}$ ) subtidal rocks. By contrast, Hexaplex trunculus is found only subtidally in more quiescent littoral environments (shallow bays and lagoons or deeper in wave-exposed sites). Morphologically, $S$. haemastoma is squatter than $H$. trunculus and the ratio of its foot surface area to the maximum projected surface area of its shell is $35 \%$ higher, making $S$. haemastoma less prone to dislodgment by waves. Mechanically, at least a 2-fold higher force $(12 \mathrm{~N})$ is required to dislodge $S$. haemastoma from the substrate, probably due to its larger foot, because tenacity per foot area was similar between species. The feeding technique and foraging behavior of $S$. haemastoma is also adapted to life in high-energy environments. Higher feeding rates and much shorter prey handling time compared to $H$. trunculus allow this species shorter foraging bouts that reduce the risk of dislodgment and increase predation success in wave-exposed areas. H. trunculus thrives in low-flow habitats where food density is low compared to shallow subtidal rocks. This is compensated for by a broader diet than $S$. haemastoma, feeding on any available food item, including conspecifics, and by reducing adhesion when not feeding, thus saving energy. S. haemastoma is more adapted to survive desiccation conditions than $H$. trunculus, which may exclude the latter from intertidal habitats. Our findings suggest that habitat partitioning between the whelks is maintained mainly by a 'distinct preferences' mechanism that might be relevant for other benthic predatory species.
\end{abstract}

KEY WORDS: Species distribution · Adaptation · Distinct preferences $\cdot$ Rocky shore $\cdot$ Wave action • Morphology Resale or republication not permitted without written consent of the publisher

\section{INTRODUCTION}

Habitat partitioning among organisms is usually attributed to distinct or shared preferences (Wisheu 1998). Distinct preferences occur when species partition a habitat because each performs best in a distinct niche along a gradient. Shared preferences occur when negative interactions, such as competition, force the subordinate to occupy regions with sub-optimal levels of resources. The rocky shores, a highly species rich environment, has been a subject of numerous studies on the distribution patterns of organisms and the mechanisms (e.g. limiting physical conditions, biotic interactions) responsible for them (Stephenson \& Stephenson 1949, Lewis 1964, for review see Menge \& Branch 2001). Habitat partitioning of closely related 
species can occur on rocky shores on relatively small spatial scales due to the sharp gradients in environmental conditions. For example, zonation of related species is often attributed to differential tolerance to desiccation and thermal stress (e.g. barnacles, Connell 1961; limpets, Davenport 1997; topshells, Little \& Kitching 1996; mussels, Simpfendorfer et al. 1995), or sedimentation (mussels, Iwasaki 1995). Differential predation (e.g. predation on limpets by birds, Hahn \& Denny 1989), congeneric predation (e.g. in sea stars, Stevenson 1992), or differences in diet (e.g. in crustaceans, Hudon \& Lamarche 1989) can also lead to habitat partitioning. Wave action has a major effect on the distribution patterns of rocky shore organisms, and its magnitude determines both the abundance and community effects of mobile predators such as sea stars and whelks (environmental stress models, see Menge \& Sutherland 1987). Two aspects of a mobile predator in a rocky shore can strongly influence its adaptation to wave action. One is its ability to resist dislodgment and the other is its feeding efficiency (prey handling time). In wave-exposed environments, related species that differ in these characteristics are expected to demonstrate habitat partitioning. In this paper, we test this general hypothesis using 2 Mediterranean whelks.

The relationship between exposure to wave action and risk of dislodgment of littoral organisms is well established and attributed to various morphological and biomechanical (adhesion) adaptations (Denny 1985, 1994, Denny et al. 1985, Denny \& Gaines 1990, Trussell 1997). Gastropods resist dislodgment by adhering to the substratum with their foot, where the adhesion strength is positively correlated with surface area, and the strength and thickness of the mucus (Cottrell 1964). The adhesion efficiency of the snail is a function of the allometric relation of shell projected area (that determines drag) and foot area (Denny et al. 1985, Trussell 1997). Consequently, snails such as whelks, topshells and periwinkles are more susceptible to dislodgment by waves than limpets due to their higher shell shape and lower adhesive tenacity (adhesion strength per foot area, Denny 1985). Vermeij (1973) related differences in morphology of high-intertidal herbivorous gastropods from different taxonomic groups (littorinids, limpets, neritids) mainly to differential resistance to desiccation but did not consider differential risk of dislodgment. Comparison among snail populations from protected and exposed sites demonstrated phenotypic plasticity as an adaptation to risk of dislodgment. Periwinkles (Trussell et al. 1993, Trussell 1997), topshells (Frid \& Fordham 1994) and whelks (Gibbs 1993, Hughes \& Taylor 1997) on wave-exposed shores have squatter shells, and larger shell aperture and foot, than their conspecifics on wave-protected shores.
In addition, in rocky shores, the amount of time a predator spends foraging exposed on the rocks influences its susceptibility to dislodgment by waves. In exposed sites, whelks spend time foraging out of shelter only when the environment is 'mechanically safe' (Menge 1978a,b, Denny et al. 1985, Moran 1985, Burrows \& Hughes 1989). Risk of dislodgment by strong currents and waves can reduce the time available for foraging (Denny et al. 1985, Judge 1988, Burrows \& Hughes 1989) and affect growth rates (Etter 1996). Predation rates of the whelk Nucella lapillus from waveexposed habitats were shown to be higher than those from protected areas (Menge 1978b). This suggests that feeding more rapidly might be beneficial in wave-exposed environments, because it allows shorter predation bouts, and reduces the risk of dislodgment. Long foraging bouts resulting from long search durations, or extended prey handling time is a disadvantage in sites with frequent wave action. Whelks appear to have evolved a variety of responses to this problem. On the Louisiana coast, whelks in wave-exposed sites switch to feeding on smaller prey and so reduce handling time (Richardson \& Brown 1990) or, when the prey (oysters) is too large to be handled efficiently by a single snail, and waves may disrupt feeding, they feed in groups (Brown \& Alexander 1994). Many predatory whelks drill the shell of their prey (Radwin \& Wells 1968, Carriker 1981). The presence, position and size of the holes reveal the feeding techniques of these whelks, and indicate possible mechanisms for reducing preyhandling time (Hughes \& Dunkin 1984, Rovero et al. 1999a). Predators employing less efficient predation techniques may have longer prey-handling time and so must avoid habitats with strong wave action.

Two predatory muricid whelks of similar size Stramonita haemastoma and Hexaplex trunculus (maximum length 65 to $77 \mathrm{~mm}$ ) are found in different habitats in the eastern Mediterranean. S. haemastoma is usually most common in the subtidal zone, on shallow, wave-exposed rocks, but is also found in the intertidal zone, in areas where food and shelter are abundant (Rilov et al. 2001). In contrast, $H$. trunculus is found only subtidally in shallow protected habitats or in deeper water in wave-exposed shores (G. Rilov pers. obs.). H. trunculus is also found offshore at greater depths (9 to $30 \mathrm{~m}$ ) on rocky or sandy bottoms (Barash \& Danin 1992, G. Rilov pers. obs.). The difference in distribution pattern of the 2 whelks suggests that they may differ in their adaptation to life in wave-exposed habitats. Because $H$. trunculus does not exist in the intertidal zone, even in protected habitats, we also suspect that it has lower resistance to desiccation than S. haemastoma.

Here, we test the following hypotheses that can explain habitat partitioning of the 2 whelks along the 
Israeli shore by distinct preferences: (1) Stramonita haemastoma is better fitted to life in high-wave-energy environments than Hexaplex trunculus due to morphological (shape), mechanical (adhesive performance) and behavioral (higher feeding rate and shorter handling time) adaptations; (2) $S$. haemastoma is better adapted to survive in air-exposed habitats (intertidal) because of higher resistance to desiccation than $H$. trunculus; (3) In the ultra-oligotrophic waters of the Israeli coast (Mergand \& Berman 1989) being a generalist (wider diet) helps $H$. trunculus to thrive in lowflow environments (protected or deeper habitats) where food is expected to be less abundant (see Leonard et al. 1998).

\section{MATERIALS AND METHODS}

Whelk distribution. We determined the distribution of Stramonita haemastoma and Hexaplex trunculus in low and high-wave-energy habitats at 4 sites along the Israeli coast, from north to south: (1) a northern site (Akhziv, September 1995) (a) on the bottom of a shallow lagoon (0.5 to $1.5 \mathrm{~m}$, mixed rocky and sandy bottom), (b) on the flat of a midlittoral platform enclosing the lagoon, (c) on the seaward wall of that platform (at a depth of 1 to $3 \mathrm{~m}$ ), (d) on a mosaic of bedrock and sand near the platform wall (at a depth of 4 to $5 \mathrm{~m}$ ) and (e) on midlittoral bench-like rocks (incisioned rocks, sensu Rilov et al. 2001) $2 \mathrm{~km}$ to the north of the lagoon, where $S$. haemastoma densities are highest along the coast (Rilov et al. 2001); (2) a site ca. $15 \mathrm{~km}$ south of Akhziv (Akko, March 1997) in a shallow (0.5 to $1.5 \mathrm{~m}$ ) protected sandy bay with scattered small boulders and rocks; (3) a site ca. $90 \mathrm{~km}$ south of Akhziv at the center of the coastal plain (Herzelia, November 1998), along a depth gradient on the seaward side of a marina breakwater, $700 \mathrm{~m}$ south of the marina opening; and (4) a site ca. $100 \mathrm{~km}$ south of Akhziv (Tel-Aviv, March 1997) (a) on the lee (protected) and (b) seaward (exposed) sides of 3 breakwaters to the south of the Tel-Aviv marina.

We determined whelk density (number $\mathrm{m}^{-2}$ ) in Akhziv and Herzelia sites by sampling $1 \times 1 \mathrm{~m}$ quadrats along transects. In Akhziv, sampling was conducted along $10 \mathrm{~m}$ transects; the number of transects depended on habitat availability and was negatively related to whelk abundance. We sampled quadrats on boulders of the Herzelia marina breakwater along transects at $1 \mathrm{~m}$ intervals from the surface to a depth of $4 \mathrm{~m}$, and on a nearby sandy bottom, up to $1 \mathrm{~m}$ from the breakwater ( $\mathrm{n}=30$ quadrats per depth).

At the other sites (Tel-Aviv, Akko), we conducted surveys of whelk abundance (number per unit effort). The duration of the surveys was $10 \mathrm{~min}$ in Tel-Aviv and
20 min in Akko (where abundance was lower). The breakwaters in Tel-Aviv were shallow (2 m) on the leeward (protected) side and deeper $(5 \mathrm{~m})$ on the seaward (exposed) side; thus, we surveyed the seaward side in shallow (1 to $3 \mathrm{~m}$ ) and deeper ( 4 to $5 \mathrm{~m}$ ) water separately.

ANOVA was preformed (STATISTICA 6, StatSoft 2001) on square-root transformed data treating species and habitat (4 sites at the lagoon site in Akhziv), depth (at the Herzelia breakwater) or exposure (at the 3 breakwaters in Tel-Aviv) as fixed factors and number of whelks in a quadrat (Akhziv \& Herzelia) or number of whelks per unit effort (Tel-Aviv) as dependent variables.

In addition, we recorded the type of substrate (rocky or sandy) on which the whelks were found during surveys in Akhziv (May 1995, December 1995 and September 1996), Tel-Aviv and Herzelia (March 1997). Overall, we recorded 346 observations of Hexaplex trunculus and 465 of Stramonita haemastoma. We conducted all underwater observations by SCUBA during calm sea conditions.

Allometry and adhesive features. We collected 34 individuals of each whelk species (Stramonita haemastoma $60.9 \pm 5.1 \mathrm{SD}$ shell length, range 51 to $75 \mathrm{~mm}$; Hexaplex trunculus $46.2 \pm 7.1$, 30 to $61 \mathrm{~mm}$ ) in November 1998 from the Herzelia marina breakwater. We avoided using small individuals to reduce the possibility of co-variation between size and allometric ratios, and scattered plots confirmed the lack of such co-variation in the tested size classes. In the laboratory, we placed the snails in 801 aquaria for $2 \mathrm{~d}$ before measurements. For each snail, we traced the outline of its foot surface area onto transparency paper placed against the aquarium glass (Trussell 1997). We then removed the snail from the aquarium and traced the shell aperture area onto the transparency. Lastly, we placed the snail on its side and traced the maximum projected surface area (MPSA) of the shell, including fouling organisms. Because wave direction can vary, the MPSA of the shell (the side view) is considered the orientation exposed to the greatest drag (Trussell 1997). We traced the MPSA again after removing the fouling organisms with a scalpel. For each snail, we took measurements of shell aperture and length, and of shell height using a caliper (to the nearest $0.1 \mathrm{~mm}$ ). To calculate the area, to the nearest $1 \mathrm{~mm}^{2}$, of traces on transparencies we used computerized image analysis. Differences between allometric ratios were tested by 1-way ANOVA after arcsine transformation using species as the independent factor and ratios as the response variable.

We measured the dislodgment force of the 2 whelk species in situ at the Herzelia marina breakwater in November 1998. To determine the shear dislodgment force, we pulled whelks off the substratum by a portable dynamometer $(0$ to $20 \mathrm{~N})$. A monofilament 
fishing line (1 $\mathrm{mm}$ in diameter) was attached to the dynamometer hook and, at the other end, tied into a loop that could be gently looped around the shell parallel to the substrate (Smith 1992). We slowly pulled the snail sideways, to apply a force to the broadest side of the snail, and parallel to the substratum (simulating the drag force of the water), until the snail was dislodged. Prior to dislodgment, we recorded whether the snail was feeding, and after dislodgment we confirmed it by examining signs of predation. The maximum dislodgment force was marked by a ring on the dynamometer, which remained in place after detachment indicating maximum extension of the spring (to the nearest $0.1 \mathrm{~N}$ ) when the snail was dislodged from the substratum. We measured shell and aperture lengths of the tested snails ( $\mathrm{n}=30$ for each). Foot surface area of the dislodged snails was determined by using a regression relating aperture length to foot area (Smith 1992) obtained from the above mentioned allometric measurements. We calculated tenacity, expressed as adhesion force per unit foot area in contact with a surface, in $\mathrm{N} \mathrm{m}^{-2}$. Dislodgment force and tenacity were calculated for feeding and non-feeding individuals separately. Square-root transformed data were analyzed using 2-way ANOVA with species and feeding activity as fixed factors and Fisher Exact post hoc analysis was applied.

Feeding behavior features. We compared predation rates (prey items $\mathrm{d}^{-1}$ ) and prey handling time of the 2 whelk species under laboratory conditions. In May 1995, a period when both whelks are active (Spanier 1986, Rilov et al. 2001), we collected 8 whelks (50 to $60 \mathrm{~mm}$ shell length) of each species in Akhziv. Fouling organisms were removed from the shell and the snails were acclimated separately in the laboratory for $2 \mathrm{wk}$ without feeding, each in a $10 \mathrm{l}$ aquarium containing aerated artificial seawater $\left(24\right.$ to $\left.26^{\circ} \mathrm{C}\right)$. One-third of the water in the aquaria was replaced every other day. We used as prey the mussel Brachidontes pharaonis of the family Mytilidae. This mussel was readily obtained and was found to be a preferred food item of Stramonita haemastoma (Rilov et al. 2002), and eaten by Hexaplex trunculus in our preliminary field and laboratory observations. Each snail was offered 5 large (25 to $30 \mathrm{~mm}$ ) and 5 small (5 to $10 \mathrm{~mm}$ ) mussels. Consumed mussels were replaced daily. We recorded feeding activity 3 to 4 times between 08:00 and 18:00 $\mathrm{h}$ and once at night for $18 \mathrm{~d}$ in $S$. haemastoma and $25 \mathrm{~d}$ in $H$. trunculus. Prey handling time was defined as the time the snail spent drilling and ingesting the prey, and was approximated as the interval during which the snail was observed present on the mussel, plus one half of the time interval preceding and following that observation, following Brown \& Richardson (1987). A 2-way ANOVA was performed on square-root arcsine transformed data with whelk species and prey size as fixed factors.
We recorded the occurrence, position and size of drill holes made by the 2 whelk species on mussels that were eaten during the experiments. We determined 6 hole position-categories: 4 'marginal' positions (up to $2 \mathrm{~mm}$ from the edge of the valve, identified as on a concave or convex side, or at anterior or posterior ends of the valve; and 2 central hole positions, identified as on the left or right valve. The drill hole was usually elliptical in shape and thus, its area was calculated from measurements of the length and width of the hole (to the nearest $0.1 \mathrm{~mm}$ ), using a dissecting microscope equipped with an eye-piece graticule. Drill hole size of the 2 species was compared using a $t$-test. Shell thickness in different areas of each of the 2 valves ( $n=31$ ) was measured using a digital caliper (to the nearest $0.01 \mathrm{~mm}$ ) and compared using 1-way ANOVA.

Resistance to exposure to air. We tested the relative survivorship of the 2 whelk species when exposed to desiccation in the laboratory. We collected 10 snails from Herzelia in November 1998. The whelks were placed in $40 \mathrm{l}$ aquaria with aerated artificial seawater for $3 \mathrm{~d}$ in a temperature-controlled room. Temperatures inside the aquaria varied between 23 and $27^{\circ} \mathrm{C}_{i}$ within the range of spring and early summer temperatures along the Israeli coast. We then placed pairs of Stramonita haemastoma and Hexaplex trunculus inside $10 \mathrm{l}$ aquaria without water $(\mathrm{n}=10)$. Every $8 \mathrm{~h}$ for $5 \mathrm{~d}$, we recorded whether the snails were alive (dead snails quickly develop strong odors). Mortality was verified at the end of the experiment by submerging the snails in sea water for evidence of recovery (reattachment and movement) and rates were compared using 1-way ANOVA.

Food density and diet. We determined the density of barnacles, mussels and limpets, common prey items of whelks (Navarrete \& Menge 1996, Rilov et al. 2002), on boulders at the Herzelia marina breakwater (where the 2 whelks exhibit vertical partitioning zonation) at 1, 2 and $4 \mathrm{~m}$ depths (November 1998). The number of barnacles, mainly Balanus perforatus, the mussel Brachidontes pharaonis and the limpet Patella caerulea, was counted within a frame of $10 \times 10 \mathrm{~cm}$ laid at $1 \mathrm{~m}$ intervals along a $30 \mathrm{~m}$ transect $(\mathrm{n}=30$ quadrats at each depth). We conducted a quantitative survey in Herzelia marina breakwater (November 1998) to determine the percentage of different food items in the diet of Stramonita haemastoma and Hexaplex trunculus. We scanned the boulders of the breakwater and the surrounding sand for $1 \mathrm{~h}$, and recorded the type and number of food items on which the whelks were found. Additional partially qualitative information on food items of the whelks came from field and laboratory records taken throughout the entire study period (1995 to 1998). 


\section{RESULTS}

\section{Whelk distribution}

Habitat type (Akhziv site), depth (Herzelia site) and the degree of exposure to waves (Tel-Aviv site) all effected the distribution patterns of both species (Table 1). Hexaplex trunculus was relatively common ( $>1$ individual per minute survey or $>1$ individual $\mathrm{m}^{-2}$ ) in low-wave-energy habitats, i.e. shallow bay or lagoon, horizontal bedrock at a depth of 4 to $5 \mathrm{~m}$ at the seaward side of the platform, the leeward side of breakwaters and the deeper sections of the exposed side of breakwaters (Fig. 1). H. trunculus was also found on the sand among boulders in the Herzelia marina breakwater. Stramonita haemastoma was absent or rare at most of these habitats but was relatively common ( $>4$ individuals per minute survey, or $>0.5$ individual $\mathrm{m}^{-2}$ ) on the platform wall and at the shallow depth (1 to $3 \mathrm{~m}$ ) on the exposed side of breakwaters, except for the deeper wave-exposed faces of the breakwaters in Tel-Aviv where the 2 species equaled in abundance (Fig. 1a).

Table 1. Stramonita haemastoma and Hexaplex trunculus. One-way ANOVA of the effect of habitat (lagoon, platform flat, platform wall and bedrock; Akhziv, northern site) and depth (seaward side of a breakwater; Herzelia site) on density (ind. $\mathrm{m}^{-2}$ ), and the effect of exposure (breakwaters;Tel-Aviv site) on individuals found per minute search. Values were square root transformed before analysis

\begin{tabular}{|c|c|c|c|c|c|c|c|}
\hline Site & Species & Factor & SS & df & MS & $F$ & $\mathrm{p}$ \\
\hline \multirow[t]{4}{*}{ Akhziv } & \multirow[t]{2}{*}{ Hexaplex trunculus } & Habitat & 19.76 & 3 & 6.58 & \multirow[t]{2}{*}{38.26} & \multirow[t]{2}{*}{$<0.0001$} \\
\hline & & Error & 26.17 & 152 & 0.17 & & \\
\hline & \multirow[t]{2}{*}{ Stramonita haemastoma } & Habitat & 1.89 & 3 & 0.63 & \multirow[t]{2}{*}{3.40} & \multirow[t]{2}{*}{0.02} \\
\hline & & Error & 28.40 & 153 & 0.18 & & \\
\hline \multirow[t]{4}{*}{ Herzelia } & \multirow[t]{2}{*}{ Hexaplex trunculus } & Depth & 13.72 & 4 & 3.43 & \multirow[t]{2}{*}{21.56} & \multirow[t]{2}{*}{$<0.0001$} \\
\hline & & Error & 19.09 & 120 & 0.15 & & \\
\hline & \multirow{2}{*}{ Stramonita haemastoma } & Depth & 14.39 & 4 & 3.59 & \multirow[t]{2}{*}{13.70} & \multirow[t]{2}{*}{$<0.0001$} \\
\hline & & Error & 31.50 & 120 & 0.26 & & \\
\hline \multirow[t]{4}{*}{ Tel-Aviv } & \multirow[t]{2}{*}{ Hexaplex trunculus } & Exposure & 6.40 & 2 & 3.20 & \multirow[t]{2}{*}{86.82} & \multirow[t]{2}{*}{$<0.0001$} \\
\hline & & Error & 0.22 & 6 & 0.03 & & \\
\hline & \multirow[t]{2}{*}{ Stramonita haemastoma } & Exposure & 9.12 & 2 & 4.56 & \multirow[t]{2}{*}{771.70} & \multirow[t]{2}{*}{$<0.0001$} \\
\hline & & Error & 0.035 & 6 & 0.005 & & \\
\hline
\end{tabular}
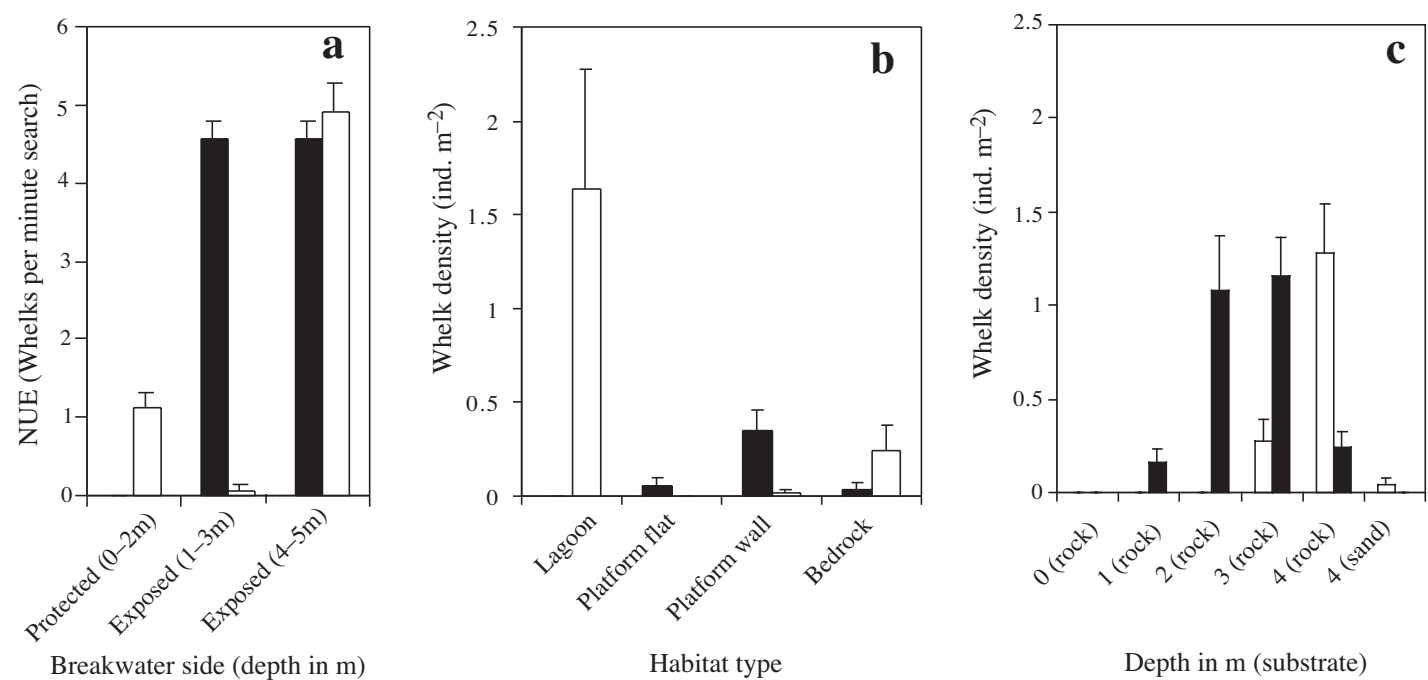

Fig. 1. Abundance of Stramonita haemastoma (black bars) and Hexaplex trunculus (open bars). (a) Average number (+SE) of snails counted per unit effort (NUE; $\mathrm{min}$ ) on the lee (protected) and windward (exposed) sides of breakwaters in Tel-Aviv. $\mathrm{n}=35$, 20,50 and 50 for lagoon, platform, wall and bedrock, respectively. (b) Density (+SE) of snails at 4 habitat types in Akhziv (n = 35 to 50 quadrats at each habitat). (c) Density $(+\mathrm{SE})$ of snails at different depths and substrate types at the Herzelia marina wave breaker ( $\mathrm{n}=30$ at each depth) 
Table 2. Stramonita haemastoma and Hexaplex trunculus. Comparison of allometric relationships between the species, presented as ratios (average $\pm \mathrm{SD}$ ) between the different morphological variables for each species. Differences between ratios were tested by 1-way ANOVA after arcsine transformation, and the $F$ and p values are presented. $F_{\mathrm{c}}$ (critical $F$ value) $=3.99$. MPSA $=$ maximum projected surface area $;+$ fouling $=$ area measured before fouling was removed from the shell $;-$ fouling $=$ area measured after fouling was removed from the shell

\begin{tabular}{|llcrrr|}
\hline & & \multicolumn{2}{c|}{ Variable I/Variable II } & \\
Variable I & Variable II & Stramonita haemastoma & Hexaplex trunculus & $F_{1,67}$ & $\mathrm{p}$ \\
\hline Aperture length & Shell height & $1.08 \pm 0.08$ & $0.81 \pm 0.08$ & 192.2 & $<<0.0001$ \\
Shell height & MPSA -fouling & $0.025 \pm 0.003$ & $0.039 \pm 0.008$ & 74.9 & $<<0.0001$ \\
Foot area & MPSA +fouling & $0.44 \pm 0.09$ & $0.35 \pm 0.09$ & 16.5 & $=0.0001$ \\
Foot area & MPSA -fouling & $0.50 \pm 0.09$ & $0.37 \pm 0.09$ & 27.2 & $<0.0001$ \\
\hline
\end{tabular}

\section{Allometry and adhesive features}

Stramonita haemastoma has a squatter shell than Hexaplex trunculus as indicated by a $33 \%$ higher ratio of aperture length to shell height and by a $36 \%$ lower ratio of shell height to MPSA (without fouling, Table 2). $S$. haemastoma also had a 20 to $26 \%$ greater ratio of foot area to MPSA than $H$. trunculus, with and without fouling, respectively. The fouling on the shell significantly reduced the ratio of foot area to maximum projected surface area in S. haemastoma (by $13 \%$, ANOVA, $F_{1,67}=6.98, \mathrm{p}=0.01$ ) but not in $H$. trunculus that was less fouled.

The regression equations obtained for the relationship between aperture length and foot area are: foot area $=15.8$ (aperture length) $+78.2\left(\mathrm{r}^{2}=0.33, \mathrm{p}=\right.$ 0.002) for Stramonita haemastoma, and foot area = 15.4 (aperture length) - $50.9\left(\mathrm{r}^{2}=0.43, \mathrm{p}=0.004\right)$ for Hexaplex trunculus. These equations were used for the calculation of foot area of whelks measured in the field. Fouling (mainly barnacles and tube worms) comprised $11.7 \pm 7.5 \%$ (SD) of the maximum projected surface area in $S$. haemastoma, which is twice that found for $H$. trunculus $\left(6.0 \pm 5.8 \%, F_{1,68}=11.7\right.$, $\mathrm{p}=0.0001$, 1-way ANOVA after arcsine transformation).

The mean shell length of Stramonita haemastoma tested in the field for adhesion strength was $60.2 \pm$ $4.7 \mathrm{~mm}(\mathrm{SD})$ and that of Hexaplex trunculus, $44.0 \pm$ $7.5 \mathrm{~mm}$. The 2-way ANOVA results demonstrate that both dislodgment and tenacity differ between species and, in $H$. trunculus, also between feeding and nonfeeding individuals producing an interaction between species and feeding (Table 3). Similar shear dislodgment force was measured in feeding and non-feeding $S$. haemastoma whereas in $H$. trunculus, feeding individuals were holding on to the substrate much more firmly (Fig. 2a). The shear dislodgment force of feeding $S$. haemastoma was more than twice as high as in feeding $H$. trunculus and was an order of magnitude higher in non-feeding $S$. haemastoma individuals as in non-feeding $H$. trunculus (Fig. 2a). Comparison of the tenacity revealed that the feeding individuals of the 2 species had a similar adhesion force per foot area, but non-feeding individuals of H. trunculus had lower tenacity (Fig. 2b).
Table 3. Stramonita haemastoma and Hexaplex trunculus. Effect of species and foraging activity on shear dislodgment force and tenacity. Two-way ANOVA on square-root transformed data

\begin{tabular}{|lrrrrc|}
\hline & SS & df & MS & \multicolumn{1}{c|}{$F$} & $\mathrm{p}$ \\
\hline Dislodgment & & & & & \\
Species & 60.26 & 1 & 60.26 & 147.46 & $<0.0001$ \\
Feeding/non-Feeding & 15.53 & 1 & 15.53 & 38.00 & $<0.0001$ \\
Species $\times$ Feeding/non-Feeding & 5.33 & 1 & 5.33 & 13.03 & 0.000653 \\
Error & 22.89 & 56 & 0.41 & & \\
& & & & & \\
Tenacity & & & & & \\
Species & 0.028 & 1 & 0.028 & 32.93 & $<0.0001$ \\
Feeding/non-Feeding & 0.056 & 1 & 0.056 & 65.28 & $<0.0001$ \\
Species $\times$ Feeding/non-Feeding & 0.034 & 1 & 0.034 & 39.85 & $<0.0001$ \\
Error & 0.048 & 56 & 0.0008 & & \\
\hline
\end{tabular}

\section{Feeding behavior features}

The predation rate of Stramonita haemastoma was higher than that of Hexaplex trunculus and both whelks eat more large than small mussels. $S$. haemastoma ate $0.32 \pm 0.08( \pm \mathrm{SE})$ and $0.04 \pm 0.02$, large and small mussels per day, respectively. $H$. trunculus ate $0.08 \pm 0.02$ and $0.01 \pm 0.008$, large and small mussels, respectively (2-way ANOVA; species effect: $F_{1,20}=$ 13.48, p $<0.0001$, prey size effect: $F_{1,20}=5.13 \mathrm{p}=0.03$, no species $\times$ prey size interaction). Handling time when feeding on large mussels was 10 
times shorter in $S$. haemastoma than in $H$. trunculus (range of 3 to 16 with a mean of $9.2 \pm 3.6 \mathrm{~h}$ and range of 30 to 210 with a mean of $97.2 \pm 58.1 \mathrm{~h}$, respectively, $F_{1,31}=48.9, \mathrm{p} \ll 0.0001,1$-way ANOVA). Preying on small mussels was a short episode in both whelks and was completed in less than $4 \mathrm{~h}$ (the period between consecutive observations).

More mussels, large or small, had drill holes when preyed upon by Hexaplex trunculus compared to Stramonita haemastoma (large mussels: $96 \%$ compared to $76 \%, \mathrm{n}=30$ and 51, respectively; small mussels: $72 \%$ compared to $54 \%, \mathrm{n}=12$ and 48, respectively). All drill holes made by $S$. haemastoma in both large and small mussels were in the margin of the valves and $>60 \%$ of these holes were at the center of the concave side of the mussel. Most (80 to $90 \%$ ) of the mussels preyed upon by $H$. trunculus had drill holes in the margins; the majority were located at the center of the concave side of the valve (38 and $20 \%$, for large and small mussels, respectively), or at the anterior end of the valve (40 and $60 \%$ ).

The drill hole made by Stramonita haemastoma was in the form of a narrow slit at the margin of the valve, many times eroding mainly the organic layer of the valve. The drill hole made by Hexaplex trunculus was often found in the thicker areas of the mussel's valve (the anterior and center) and had a conical shape. Both the outer $\left(46 \mathrm{~mm}^{2}\right)$ and inner $\left(18 \mathrm{~mm}^{2}\right)$ openings of the conical drill made by $H$. trunculus were significantly ( $p<0.0001)$ larger than the hole made by $S$. haemastoma $\left(3 \mathrm{~mm}^{2}\right)$.

We found strong positive correlation between shell length and thickness; for example, $\mathrm{r}^{2}=0.59$, $\mathrm{p}<0.001$; for the concave side of the valve. The shell thickness of both valves was similar. The thinnest area of the valve was the concave side $(0.41 \pm 0.14 \mathrm{~mm})$, whereas the anterior side was thicker by $26 \%(0.51 \pm 0.18)$, the convex side by $59 \%(0.64 \pm 0.17 \mathrm{~mm})$ and the center of the valve by $173 \%\left(1.13 \pm 0.41 \mathrm{~mm} ; F_{1,30}=5.1, \mathrm{p}=0.02\right.$; $F_{1,30}=31.1, \mathrm{p}<<0.001 ; F_{1,30}=83.2, \mathrm{p}<<0.001$, respectively, ANOVA).

\section{Resistance to exposure to air}

Most individuals of Stramonita haemastoma retreated into their shell within the first day of exposure to air, whereas almost all Hexaplex trunculus extruded their foot until they died. $50 \%$ mortality was recorded after 60 and $102 \mathrm{~h}$ of exposure to air in H. trunculus and $S$. haemastoma, respectively. Average survival time was twice as high in $S$. haemastoma than in $H$. trunculus $\left(104 \pm 25\right.$ and $58 \pm 17 \mathrm{~h}$, respectively, $F_{1,18}=23.7, \mathrm{p}=$ 0.0001 ; 1 -way ANOVA after square-root arcsine transformation).
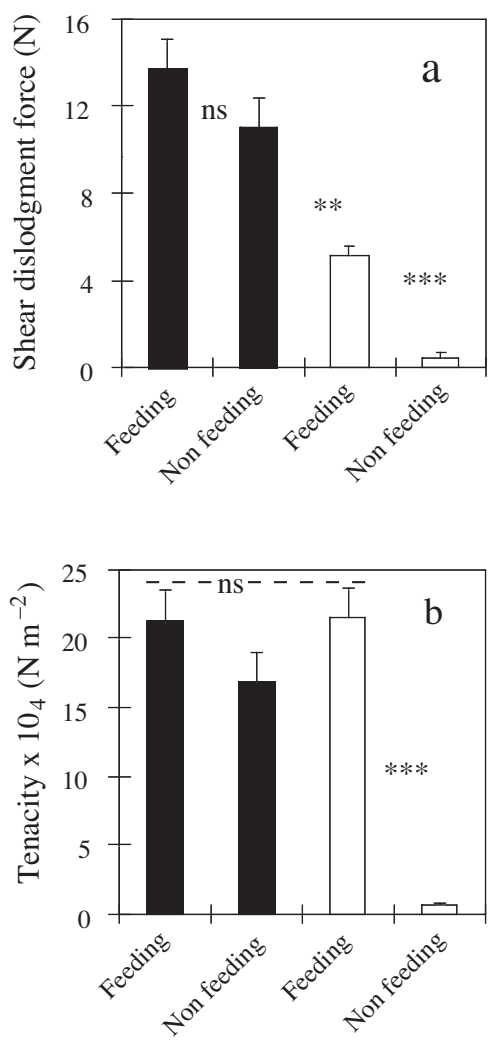

Fig. 2. (a) Shear dislodgment force and (b) tenacity in feeding and non-feeding individuals of Stramonita haemastoma (black bars) and Hexaplex trunculus (open bars). Error bars are $+\mathrm{SE}$. A dashed line is drawn above values that do not differ significantly. $* * \mathrm{p}<0.01, * * * \mathrm{p}<0.001, \mathrm{~ns}=$ not significant

\section{Food density and diet}

The density of mussels (Brachidontes pharaonis), barnacles (mainly Balanus perforatus) and limpets (Patella caerulea) on vertical infralittoral substrate decreased substantially with depth and proximity to sandy bottom (Fig. 3). Barnacles and limpets were most abundant at $1 \mathrm{~m}$, and the mussel Brachidontes pharaonis was rare below the depth of $2 \mathrm{~m}$, near the sandy bottom. During a $1 \mathrm{~h}$ dive, we observed individual Hexaplex trunculus feeding on 9 different food items and Stramonita haemastoma only on 3, mainly mussels (Fig. 4). Barnacles were abundant in the diet of both species. Most individuals (90\%) of S. haemastoma were engaged in feeding compared to about $60 \%$ of the $H$. trunculus. The non-feeding individuals of the latter species were found mainly on sand, rock or turf alga. Over the entire study, the diet of S. haemastoma included 6 prey types whereas that of $H$. trunculus included 14, including conspecifics and dead fish (Table 4). Cannibalism was frequently observed in the laboratory when $H$. trunculus were placed together 

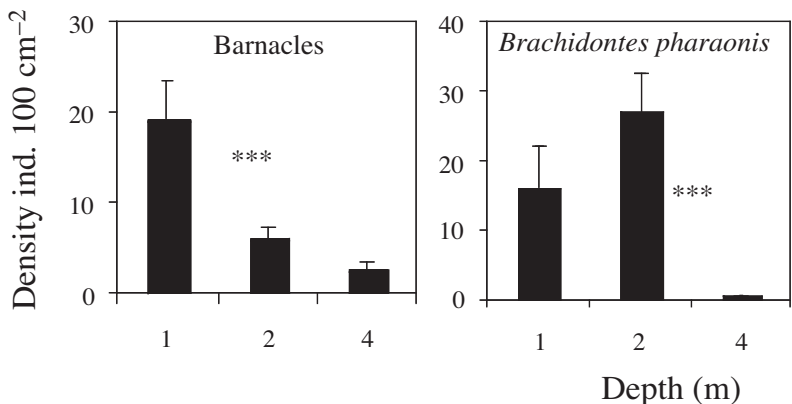

without food, but not for $S$. haemastoma under the same conditions. When the 2 species were placed together in an aquarium without food, $H$. trunculus preyed on $S$. haemastoma, but never the opposite.

\section{DISCUSSION}

Allometry and behavior have been suggested as correlates of habitat partitioning. For example, morphometric differences in closely related lizards were translated to differences in locomotive performance that were in correlation to habitat partitioning (Vanhooydonck et al. 2000). Our study supports this hypothesis

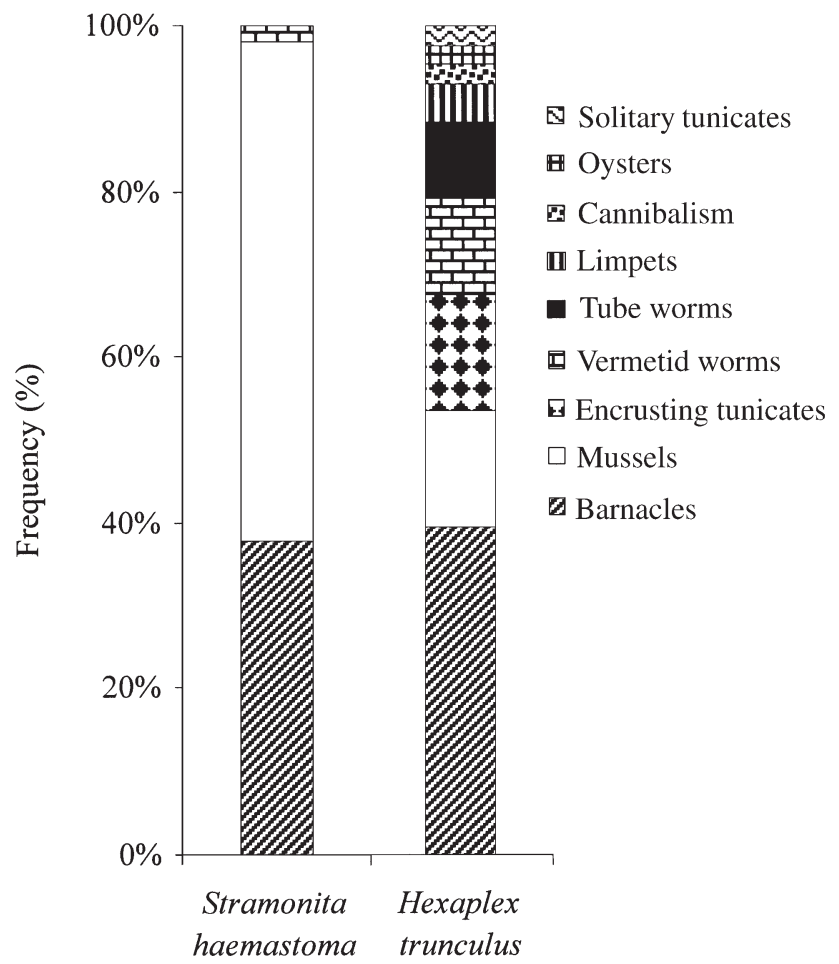

Fig. 4. Frequency of prey types that were preyed upon by Stramonita haemastoma and Hexaplex trunculus at the Herzelia marina breakwater in November 1998

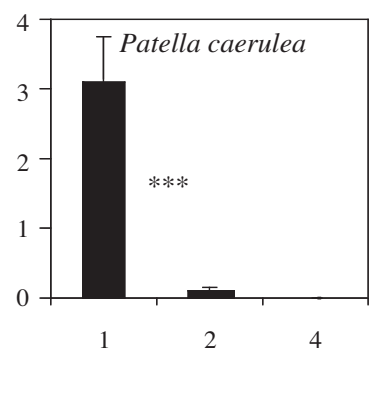

Fig. 3. Density (+SE) of main potential food items for the 2 whelk species at different depths at the Herzelia marina breakwater $(\mathrm{n}=30$ quadrats at each depth, $* * * p<0.001)$ by demonstrating that 2 relatively large predatory whelks that differ in their morphometery and feeding behavior exhibit allopatric distribution on a small spatial scale in the shallow littoral environment. We attribute this habitat partitioning to different adaptations to living in environments with high and low water movement. Rocky intertidal habitats that are directly under the influence of high wave energy offer ample food resources but expose mobile, benthic predators to high risk of dislodgment. Protected habitats such as lagoons, bays and deeper water are less risky but usually offer less food. Stramonita haemastoma appears to prefer habitats with moderate exposure to wave energy. It is most abundant on subtidal seaward rocks ( 2 to $3 \mathrm{~m}$ ) or intertidally on wave-exposed benches with abundant shelter (Rilov et al. 2001 and this study). It avoids

Table 4. Prey items of Stramonita haemastoma and Hexaplex trunculus in field and laboratory observation. $\mathrm{XXX}=$ often observed, $\mathrm{XX}=$ occasionally observed, $\mathrm{X}=$ rarely observed

\begin{tabular}{|c|c|c|}
\hline \multirow{2}{*}{ Prey item } & \multicolumn{2}{|c|}{ Predator } \\
\hline & $\begin{array}{l}\text { Stramonita } \\
\text { haemastoma }\end{array}$ & $\begin{array}{l}\text { Hexaplex } \\
\text { trunculus }\end{array}$ \\
\hline $\begin{array}{l}\text { Barnacles } \\
\text { (mainly Balanus perforatus) }\end{array}$ & $\mathrm{XXX}$ & $\mathrm{XXX}$ \\
\hline \multicolumn{3}{|l|}{ Bivalves } \\
\hline Brachidontes pharaonis & $\mathrm{XXX}$ & $\mathrm{XX}$ \\
\hline Mytilaster minimus & $\mathrm{X}^{\mathrm{a}}$ & $\mathrm{X}^{\mathrm{a}}$ \\
\hline Ostrea edulis & & $\mathrm{X}$ \\
\hline \multicolumn{3}{|l|}{ Gastropods } \\
\hline Cerithium spp. & & $\mathrm{XX}^{\mathrm{b}}$ \\
\hline Columbella rustica & & $\mathrm{X}^{\mathrm{b}}$ \\
\hline Ocinebrina edwardsi & & $\mathrm{X}^{\mathrm{b}}$ \\
\hline Stramonita haemastoma & & $\mathrm{X}^{\mathrm{a}}$ \\
\hline Hexaplex trunculus & & $\mathrm{X}$ \\
\hline Patella caerulea & $\mathrm{X}$ & $\mathrm{X}$ \\
\hline Vermetus spp. & $\mathrm{XX}$ & $\mathrm{X}$ \\
\hline Solitary tunicates & & $\mathrm{X}$ \\
\hline Encrusting bryozoans & $\mathrm{X}$ & $\mathrm{X}$ \\
\hline Fish carcass & & $\mathrm{X}$ \\
\hline \multicolumn{3}{|c|}{ aabserved only in the laboratory } \\
\hline
\end{tabular}


highly exposed shallow areas (0 to $1 \mathrm{~m}$ ) such as the upper region of breakwaters. $S$. haemastoma is also rare to absent in habitats where wave energy is low, such as lagoons, protected bays and deeper waters in exposed locations. Hexaplex trunculus avoids wave-exposed habitats and is mostly found in deeper water, or in shallow water in protected sites/habitats. Here, we discuss the significance of the biomechanical/morphological and behavioral differences between the 2 whelks that can explain their habitat partitioning.

\section{Morphological adaptations}

The morphometric differences between the 2 whelk species support our hypothesis that Stramonita haemastoma is better adapted to life in high energy environments than Hexaplex trunculus. S. haemastoma has a squatter shell shape, which is typical of waveexposed phenotypes of other snails (Trussell et al. 1993, Hughes \& Taylor 1997, Trussell 1997). Thus, the drag force acting on it by water should be smaller and the risk of dislodgment lower (Denny et al. 1985) than that acting on $H$. trunculus. Also, the surface area of the foot relative to maximum shell projection (MPSA) is larger in $S$. haemastoma than in $H$. trunculus. The adhesive tenacity of feeding individuals of the 2 species is similar; therefore, we suggest that a larger ratio of foot area to body size, and not stronger adhesiveness, is responsible for the greater force required to dislodge $S$. haemastoma from the rock. This is consistent with the findings of similar tenacity of Littorina obtusata from wave-exposed and wave-protected habitats (Trussell 1997).

The profound difference in shear dislodgment force and tenacity between feeding and non-feeding individuals of Hexaplex trunculus may be attributed to energetic considerations. Adhesion to the substrate requires energy through generation of a vacuum and/or mucus secretion. A firm adhesion is not required in the low energy environments where $H$. trunculus is found, except when clinging to prey. We suggest that when not foraging, the whelk saves energy by reducing tenacity, probably by decreasing mucus production, which is very costly (30 to $60 \%$ of assimilated energy in gastropods, Davis \& Hawkins 1998). Conserving energy may be advantageous in the relatively prey-impoverished environments where $H$. trunculus is found. On the other hand, a snail such as Stramonita haemastoma that lives in high-energy environments always faces a threat of potential dislodgment. Its strong attachment to the surface is consistent with this argument.

The tenacity measured for Stramonita haemastoma and Hexaplex trunculus is relatively similar to that measured in 2 Pacific whelks and in periwinkles,
Table 5. Adhesive tenacity (shear strength) in littoral gastropods (measured when the animal was stationary)

\begin{tabular}{|c|c|c|}
\hline Species & $\begin{array}{l}\text { Tenacity } \\
\left(10^{3} \mathrm{~N} \mathrm{~m}^{-3}\right)\end{array}$ & Source \\
\hline \multicolumn{3}{|l|}{ Snails } \\
\hline Stramonita haemastoma & 21.2 & This study \\
\hline Hexaplex trunculus & 21.5 & This study \\
\hline Thais canaliculata & 17.8 & Denny et al. (1985) \\
\hline Thais emarginata & 21.3 & Denny et al. (1985) \\
\hline Littorina scutulata & 31 & Denny et al. (1985) \\
\hline Littorina obtusata & 9.8 & Trussell (1997) \\
\hline \multicolumn{3}{|l|}{ Limpets } \\
\hline Colisella digitalis & 385 & Denny et al. (1985) \\
\hline $\begin{array}{l}\text { Mocclintockia scabra, } \\
\text { Lottia pelta, } \\
\text { L. digitalis, L. limatula }\end{array}$ & $\left.\begin{array}{c}129^{\mathrm{a}} \text { (high tide) } \\
\text { and } \\
194^{\mathrm{a}} \text { (low tide) }\end{array}\right\}$ & Smith (1992) \\
\hline${ }^{\mathrm{a}}$ Mean of 4 limpet specie & & \\
\hline
\end{tabular}

which are much smaller in size (Table 5). Interestingly, the tenacity of these littoral snails is lower than that of limpets by about an order of magnitude (Table 5). Limpets were reported to use either suction (when active) or glue-like adhesion (when not active) as adhesion mechanisms, and suction produces lower tenacity (Smith 1992, see Table 4, this study). When risk of dislodgment increases, limpets remain exposed on the rocks in high-energy environments. In contrast, under such conditions snails move away and aggregate inside shelters until the environment is mechanically safe (Menge 1978a,b, Denny et al. 1985, Fairweather 1988, Burrows \& Hughes1989, Johnson et al. 1998, Rilov et al. 2001). This behavior and the lower tenacity may suggest that snails use mainly suction to adhere to the rocks. Comparison of the density of pedal mucus glands (see Davis \& Hawkins 1998) or mucus adhesiveness qualities between snails and limpets may help clarify this aspect.

We found that Hexaplex trunculus had considerably less fouling on the shell than Stramonita haemastoma. Fouling increases projected surface, consequently reducing the ratio of foot area to MPSA (our study), and thus increasing the potential drag acting on the shell (see Denny et al. 1985, Wahl 1996). H. trunculus was often observed partially buried in sand (G. Rilov, pers. obs.) and was also reported to retreat into sand, mainly during the summer months, when it is less active (Spanier 1986). Temporary shielding from planktonic settlers, suffocation and/or erosion of biofouling by sand can explain the difference in fouling of the 2 species. This is supported by observations that individuals of $S$. haemastoma found in holes in the intertidal zone that were filled with sand had lower fouling than their conspecifics in the subtidal zone (G. Rilov unpubl. 
data). Similarly, epibiotic cover was lower in burrowing versus non-burrowing individuals of a crab species (Wahl et al. 1998). Intertidal S. haemastoma were also more clumped (Rilov et al. 2001, G. Rilov pers. obs.). This may suggest that mucus secretion, bulldozing and mutual predation on epibiosis contributes to the lower fouling on their shell (see Wahl \& Sonnichsen 1992).

\section{Feeding behavior adaptations}

Time is of the essence on the rocky shore and long prey handling times may have detrimental fitness costs (Rovero et al. 2000). The feeding experiment supports our hypothesis that Stramonita haemastoma is better adapted to life in high-energy environments than Hexaplex trunculus. Large $S$. haemastoma handle mussels for several hours, which falls within the range recorded for large $S$. haemastoma preying on mussels in Louisiana (Brown \& Richardson 1987). Prey handling-time of $S$. haemastoma on mussels is about 10 times shorter than that of $H$. trunculus, and correspondingly its predation rates are much higher. Wave action can considerably limit the foraging activity of whelks (Menge 1978b, G. Rilov et al. unpubl. data). Because the 'window of opportunity' for foraging of $S$. haemastoma in the Israeli rocky intertidal zone is extremely limited (G. Rilov et al. unpubl. data), short handling times and a high predation rate are highly advantageous. The handling time of large mussels by $H$. trunculus takes $2 \mathrm{~d}$ or more. In the eastern Mediterranean, calm seas occur infrequently except for short limited periods in fall and spring. It is, therefore, likely that snails in exposed sites will experience high wave action on a daily basis, forcing $H$. trunculus to avoid such habitats.

Prey handling times of the 2 whelk species correlate with the location and size of the drill hole that they make in the shell of their prey. Stramonita haemastoma drills a tiny hole, always in a marginal area in the middle of the concave side of the valve, the thinnest area of the mussel's shell. Drilling in marginal areas of the prey's shell (oysters) was found also for $S$. haemastoma (=Thais floridana) from the Gulf of Mexico (Radwin \& Wells 1968, Roller et al. 1984). Hexaplex trunculus drills a much larger hole and not always in the thinnest area. Drilling a small hole in the thinnest area is no doubt faster.

Based on prey handling time, drill hole size and location, prey shell thickness and drilling rates (from the literature), we conclude that Stramonita haemastoma and Hexaplex trunculus have different predation techniques. Drilling rate in muricid whelks was estimated to be 0.29 to $0.36 \mathrm{~mm} \mathrm{~d}^{-1}$ (Carriker \& Van Zandt 1972, Hughes \& Dunkin 1984, Rovero et al. 1999a). Applying this rate to the 2 whelks we studied means that it would take almost one and a half days to drill a complete hole in the thinnest part of the shell of Brachidontes pharaonis $(0.41 \mathrm{~mm})$. The tiny hole made by $S$. haemastoma (usually $<0.8 \mathrm{~mm}$ at the narrow diameter) and the short handling time ( 3 to $16 \mathrm{~h}$ ) suggest that it does not feed through the hole. The tiny hole is evidently much narrower than the snail's proboscis (2 to $3 \mathrm{~mm}$ in diameter, as estimated from Fig. 1 in Roller et al. 1984). Alternatively, S. haemastoma may inject a relaxant into the mussel's mantle cavity through the tiny hole that it has rasped with its radula, affecting the adductor muscle and causing the valves to gape (see also Whittaker 1960, Garton \& Stickle 1980, Roller et al. 1984, Rovero et al. 1999a,b). The relaxant may be strong enough to penetrate through natural gaps in the margins of the shell of small mussels (McGraw \& Gunter 1972), opening the mussel without drilling. We indeed found preyed mussels without drill holes, mostly small ones. Drilling rates exceeding $24 \mathrm{~h}$ fit handling time, size and drill hole location of $H$. trunculus. Unlike $S$. haemastoma, $H$. trunculus probably uses the large hole it created to introduce its proboscis through the shell in order to feed on the mussel flesh.

\section{Behavioral adaptation to exposure to air}

Another aspect of behavioral adaptation to living in wave-exposed environments is associated with resistance to desiccation. The intertidal habitat that is frequently under the influence of strong wave action is also at times exposed to air. Intertidal rocks in the eastern Mediterranean can sometimes be exposed for periods of several days (on calm days when the barometric pressure is high). Organisms living in this environment must cope with this stressful condition. Experiments in which the 2 whelk species were exposed to air show that Stramonita haemastoma can withstand longer periods of desiccation than Hexaplex trunculus. When exposed to warm air, $S$. haemastoma retreats rapidly into its shell and thus, reduces loss of moisture. Under the same conditions, $H$. trunculus keeps its foot protruded outside the shell and eventually dies. This difference in behavioral response to air exposure can explain the lower resistance to desiccation of $H$. trunculus. It correlates with the fact that the latter species is never found intertidally as is $S$. haemastoma. Our finding agrees with that of other studies that show that the distribution of intertidal organisms, even of closely related species, correlate with their resistance to desiccation (e.g. Iwasaki 1995, Simpfendorfer et al. 1995, Davenport 1997). Although $S$. haemastoma seems to be better adapted to cope with desiccation than $H$. trunculus, it avoids desiccation conditions by retreating to shelters in the midlittoral zone when such conditions develop (G. Rilov et al. 
unpubl. data). When trapped for several days on drying platforms, S. haemastoma will die (Rilov et al. 2001).

\section{Diet adaptations: specialist versus generalist?}

We found that Hexaplex trunculus, which lives in habitats where food density is low, has a broader diet than Stramonita haemastoma that inhabits environments richer in potential food. Unlike S. haemastoma, $H$. trunculus supplements its diet by scavenging and cannibalism. The former may not be an option in wave exposed environments because dead material can be swept away. In the laboratory, we observed $H$. trunculus preying on $S$. haemastoma, but never the opposite. This biotic interaction further justifies the species habitat segregation.

\section{CONCLUSIONS}

Our findings support a conclusion that 'distinct preferences' is the major mechanism responsible for the habitat partitioning of the 2 whelks. We base it on the snails' allometric and behavioral adaptations to life in such environments. The squatter shell of Stramonita haemastoma, which reduces the drag force acting on its body, and its larger foot surface area relative to maximum shell projection, make this species more adapted to living in wave swept environments than Hexaplex trunculus. The mode of feeding that enables $S$. haemastoma to consume food more rapidly than $H$. trunculus and its foot retracting response when exposed to air, which enables it to better cope with desiccation, further supports its existence in high flow environments. $H$. trunculus is at high risk in wave-exposed habitats but flourishes in protected environments where it capitalizes on any available animal-food resource. It is less obvious why $S$. haemastoma should avoid low-flow subtidal habitats. The answer might be shortage of food for the more restricted diet that this species possesses. Potential negative biotic interactions between the 2 (predation of $S$. haemastoma by $H$. trunculus) may also stabilize the partitioning of the habitat between these whelks, $S$. haemastoma avoiding areas where $H$. trunculus is found. We cannot rule out the possibility that a 'shared-preferences' mechanism can also play a role in the observed habitat partitioning; in that connection, we show that the 2 whelks have the potential to be competitors as they share similar items in their diet. However, if snails occupied different parts of the habitat because of competition or predation, then we would expect that performance in at least several of the measures examined in this study would be similar. Although habitat partitioning is often related to past or present competitive interactions among the constituent species, we have no evidence that the 2 whelk species coevolved, and thus that the partitioning is a result of competition. Reciprocal transplantation experiments will aid to resolve if competition exists in nature and contributes to the partitioning of the species.

Acknowledgements. We thank D. Schiel, L. Crowder, D. Rittschof and J. Cohen for useful comments on earlier versions of this paper. We appreciate the assistance of M. Gershon, and N. Sharon in laboratory experiments. We also thank the Akhziv Field School for accommodating G.R., and the Nature Reserves Authority for the permit to work in the nature reserves and collect animals for experiments. This work was supported by a PhD dissertation departmental grant to G.R.

\section{LITERATURE CITED}

Barash A, Danin Z (1992) Fauna Palestina, Mollusca I, Annotated list of Mediterranean molluscs of Israel and Sinai. Keter Press Enterprises, Jerusalem

Brown KM, Alexander JE Jr (1994) Group foraging in a marine gastropod predator: benefits and costs to individuals. Mar Ecol Prog Ser 112:97-105

Brown KM, Richardson TD (1987) Foraging ecology of the southern oyster drill Thais haemastoma (Grey): constraints on prey choice. J Exp Mar Biol Ecol 114:123-141

Burrows MT, Hughes RN (1989) Natural foraging of dogwhelk, Nucella lapillus (Linnaeus): the weather and whether to feed. J Molluscan Stud 55:285-295

Carriker MR (1981) Shell penetration and feeding by naticacean and muricacean predatory gastropods: a synthesis. Malacologia 20:403-422

Carriker, MR, Van Zandt D (1972) Predatory behaviour of a shell boring muricid gastropod. In: Winn HE, Olla B (eds) Behavior of marine animals: current perspectives in research. Vol 1. Invertebrates. Plenum Publishing Corporation, New York, p 157-214

Connell JH (1961) The influence of interspecific competition and other factors on the distribution of the barnacle Chthamalus stellatus. Ecology 42:710-723

Cottrell AH (1964) The mechanical properties of matter. John Wiley \& Sons, New York

Davenport J (1997) Comparisons of the biology of the intertidal subantarctic limpets Nacella concinna and Kerguelenella lateralis. J Molluscan Stud 63:39-48

Davis MS, Hawkins SJ (1998) Mucus from marine mollusks. Adv Mar Biol 34:1-71

Denny MW (1985) Wave forces on intertidal organisms: a case study. Limnol Oceanogr 30:1171-1187

Denny MW (1994) Extreme drag forces and the survival of wind- and water-swept organisms. J Exp Biol 194:97-115

Denny MW, Gaines SG (1990) On the prediction of maximum intertidal wave forces. Limnol Oceanogr 55:1-15

Denny MW, Daniel TL, Koehl MAR (1985) Mechanical limits to size in wave-swept organisms. Ecol Monogr 51:69-102

Etter RJ (1996) The effect of wave action, prey type, and foraging time on growth of the predatory snail Nucella lapillus (L). J Exp Mar Biol Ecol 96(1-2):341-356

Fairweather PG (1988) Movements on intertidal whelks (Morula marginalba and Thais orbita) in relation to availability of prey and shelter. Mar Biol 100:63-68

Frid LJ, Fordham E (1994) The morphology of the sub-littoral gastropod Gibbula cineraria (L.) along a gradient of wave action. Ophelia 40:135-146 
Garton DW, Stickle WB (1980) Effects of salinity and temperature on the predation rate of Thais haemastoma on Crassostrea virginica spat. Biol Bull (Woods Hole) 158:49-57

Gibbs PE (1993) Phenotypic changes in the progeny of $\mathrm{Nu}$ cella lapillus (Gastropoda) transplanted from and exposed shore to sheltered inlets. J Molluscan Stud 59:187-194

Hahn T, Denny M (1989) Tenacity-mediated selective predation by oystercatchers on intertidal limpets and its role in maintaining habitat partitioning by Collisella scabra and Lottia digitalis. Mar Ecol Prog Ser 53:1-10

Hudon C, Lamarche G (1989) Niche segregation between American lobster Homarus americanus and rock crab Cancer irroratus. Mar Ecol Prog Ser 52:155-168

Hughes RN, Dunkin S de B (1984) Behavioral components of prey selection by dogwhelks, Nucella lapillus (L.), feeding on mussels, Mytilus edulis L., in the laboratory. J Exp Mar Biol Ecol 77:45-68

Hughes RN, Taylor MJ (1997) Genotype-environment interactions expressed in the foraging behaviour of dogwhelks, Nucella lapillus (L.), under simulated environmental hazard. Proc R Soc Lond [Biol] 264:417-422

Iwasaki K (1995) Factors delimiting the boundary between vertically contiguous mussel beds of Septifer Virgatus (Wiegmann) and Hormamya mutabilis (Gould). Ecol Res 10(3):307-320

Johnson MP, Hughes RN, Burrows MT, Hawkins SJ (1998) Beyond the predation halo: small scale gradients in barnacle populations affected by the relative refuge value of crevices. J Exp Mar Biol Ecol 231:163-170

Judge ML (1988) The effects of increased drag on Lottia gigantea (Sowerby 1834) foraging ecology. Funct Ecol 2:363-369

Leonard GH, Levine JM, Schidt PR, Bertness MD (1998) Flow-driven variation in intertidal community structure in marine estuary. Ecology 79(4):1395-1441

Lewis JR (1964) The ecology of rocky shores. English Universities Press, London

Little C, Kitching JA 1996. The biology of rocky shores. Oxford University Press, Oxford

McGraw KA, Gunter G (1972) Observations on killing of the Virginia oyster by the gastropod radula. Malacologia 17:125-142

Menge BA (1978a) Predation intensity in a rocky intertidal community. Relation between predator foraging activity and environmental harshness. Oecologia 34:1-16

Menge BA (1978b) Predation intensity in a rocky intertidal community. Effect of and algal canopy, wave action and desiccation on predator feeding rates. Oecologia 34:17-35

Menge BA, Branch G (2001) Rocky intertidal communities. In: Bertness MD, Gaines SD, Hay ME (eds) Marine community ecology. Sinauer Associates, Sunderland, MA

Menge BA, Sutherland JP (1987) Community regulationvariation in disturbance, competition, and predation in relation to environmental stress and recruitment. Am Nat 130 (5):730-757

Mergand RO, Berman T (1989) Effects of algae on the Secchi transparency of the southeastern Mediterranean Sea. Limnol Oceanogr 34:1640-1655

Moran MJ (1985) The timing and significance of sheltering and foraging behavior of the predatory intertidal gastropod Morula marginalba Blainville (Muricidae). J Exp Mar Biol Ecol 93:103-114

Navarrette SA, Menge BA (1996) Keystone predation and interaction strength: interactive effects of predators on their main prey. Ecol Monogr 66(4):409-429

Radwin GE, Wells HW (1968) Comparative radular morphology and feeding habits of muricid gastropods from the Gulf of Mexico. Bull Mar Sci 1:72-85

Richardson TD, Brown KM (1990) Wave exposure and prey size selection in an intertidal predator. J Exp Mar Biol Ecol 142:105-120

Rilov G, Benayahu Y, Gasith A (2001) Low abundance and skewed population structure of the whelk Stramonita haemastoma along the Israeli Mediterranean coast. Mar Ecol Prog Ser 218:189-202

Rilov G, Benayahu Y, Gasith A (2002) Effect of an exotic prey on the feeding pattern of a predatory snail. Mar Environ Res 54:85-98

Roller RA, Garton DW, Stickle WB (1984) Regeneration of the proboscis, radula and odontophoral cartilage of the southern oyster drill Thais Haemastoma canaliculata (Gray) (Prosobranchia: Muricidae) after amputation. Am Malacol Bull 2:63-73

Rovero F, Hughes RN, Chelazzi G (1999a) Effect of experience on predatory behaviour of dogwhelks. Anim Behav 57:1241-1249

Rovero F, Hughes RN, Chelazzi G (1999b) Cardiac and behavioural responses of mussels to risk of predation by dogwhelks. Anim Behav 58:707-714

Rovero F, Hughes RN, Chelazzi G (2000) When time is of the essence: choosing a currency for prey-handling costs. J Anim Ecol 69(4) 683-689

Simpfendorfer RW, Vial MV, Lopez DA, Verdala M, Gonzalez ML (1995) Relationship between the aerobic and anaerobic metabolic capacities and the vertical distribution of three intertidal sessile invertebrates: Jehlius cirratus (Darwin) (Cirripedia), Perumytilus purpuratus (Lamarck) (Bivalvia) and Mytilus chilensis (Hupe) (Bivalvia). Comp Biochem Physiol B 111:615-623

Smith AM (1992) Alternation between attachment mechanisms by limpets in the field. J Exp Mar Biol Ecol 160:205-220

Spanier E (1986) Cannibalism in Muricid snails as a possible explanation for archaeological findings. J Archaeol Sci 13: 463-468

Stephenson TA, Stephenson A (1949) The universal features of zonation between the tidemarks on rocky coasts. J Ecol 38:289-305

Stevenson JP (1992) A possible modification of the distribution of the intertidal seastar Patiriella exigula (Lamark) (Echinodermata: Asteroidea) by Patiriella calcar (Lamark). J Exp Mar Biol Ecol 155:41-54

Trussell GC (1997) Phenotypic plasticity in the foot size of and intertidal snail. Ecology 78:1033-1048

Trussell GC, Johnson AS, Rudoph SG, Gilfillan ES (1993) Resistance to dislodgement: habitat and size-specific differences in morphology and tenacity in an intertidal snail. Mar Ecol Prog Ser 100:135-144

Vanhooydonck B, Van Damme R, Aerts P (2000) Ecomorphological correlates of habitat partitioning in Corsican lacertid lizards. Funct Ecol 14:358-368

Vermeij GJ (1973) Morphological patterns in high-intertidal gastropods: adaptive strategies and their limitations. Mar Biol 20:319-346

Wahl M (1996) Fouled snails in flow: potential of epibionts on Littorina littorea to increase drag and reduce snail growth rates. Mar Ecol Prog Ser 138:157-168

Wahl M, Sönnichsen H (1992) Marine epibiosis. IV. The periwinkle Littorina Littorea lacks typical antifouling defences - why are some populations so little fouled? Mar Ecol Prog Ser 88:225-235

Wahl M, Kroger K, Lenz M (1998) Non-toxic protection against epibiosis. Biofouling (1-3) 12:205-226

Whittaker VP (1960) Pharmacological active choline esters in marine gastropods. Ann N Y Acad Sci 90:695-705

Wisheu IC (1998) How organisms partition habitats: different types of community organization can produce identical patterns. Oikos 83:246-258 